\title{
Correction to: QoS-driven metaheuristic service composition schemes: a comprehensive overview
}

\author{
Mohammad Masdari ${ }^{1} \cdot$ Mehdi Nozad Bonab $^{2} \cdot$ Suat Ozdemir $^{3}$ \\ Published online: 30 April 2021 \\ ๑) Springer Nature B.V. 2021
}

\section{Correction to: Artificial Intelligence Review https://doi.org/10.1007/s10462-020-09940-4}

In the original publication of the article, the corresponding author name and the e-mail ID was incorrect. The correct name and e-mail ID is given in this correction.

The original article has been corrected.

Publisher's Note Springer Nature remains neutral with regard to jurisdictional claims in published maps and institutional affiliations.

The original article can be found online at https://doi.org/10.1007/s10462-020-09940-4.

Mohammad Masdari

M.Masdari@Iaurmia.ac.ir

Mehdi Nozad Bonab

m.nozad@marandiau.ac.ir

Suat Ozdemir

ozdemir@cs.hacettepe.edu.tr

1 Computer Engineering Department, Urmia Branch, Islamic Azad University, Urmia, Iran

2 Computer Engineering Department, Marand Branch, Islamic Azad University, Marand, Iran

3 Computer Engineering Department, Hacettepe University, Ankara, Turkey 